Saudi Journal of Business and Management Studies Abbreviated Key Title: Saudi J Bus Manag Stud ISSN 2415-6663 (Print) |ISSN 2415-6671 (Online) Scholars Middle East Publishers, Dubai, United Arab Emirates Journal homepage: https://saudijournals.com/sjbms

Original Research Article

\title{
Dividend Policy Impact on Market Value of Quoted Commercial Banks in Nigeria (2004-2018)
}

Peter E. Ayunku, Tonye Richard Apiri"

Banking \& Finance Department, Faculty of Management Sciences, Niger Delta University Wilberforce Island, Bayelsa State, Nigeria

DOI: $10.36348 /$ sjbms.2020.v05i03.002

| Received: 17.02.2020 | Accepted: 26.02.2020 | Published: 13.03.2020

*Corresponding author: Tonye Richard Apiri

\section{Abstract}

Study of dividend policy and stock prices in the capital market has attracted considerable interest in corporate finance literature. Theoretical postulates and empirical evidence from country specific and cross-country studies are divided across lines, as some support the existence of a positive significant implication while others submit entirely negative and non-significant implication on the studied topic. Thus, this paper examines Nigerian context of dividend policy impact on market value of quoted commercial banks with study range of 2004-2018. The study is hinged on the theoretical postulates of dividend relevance theory and Efficient Market Hypothesis (EMH). The study employed model stability test and Error Correction Model (ECM) after determining the stationarity status of the time series data employed in the study, using ADF test, while Johansen Co-integration test was used to predict the existence of two long-run co-integrating relationships among variables. The empirical result reveals a significant dividend policy impact on market value of quoted commercial banks in Nigeria. The study therefore, recommends that Central Bank of Nigeria (CBN), Securities and Exchange Commission (SEC) and the established Financial Regulatory council (FRC) to step up regulatory oversight functions to ensure transparency, business ethics and good corporate governance in the banking industry particularly quoted commercial banks in Nigeria, as this will help curtail the anxiety of investors and relatively reduce the practices of declaration of huge paper profits, insider trading, manipulation of stock prices and other nefarious acts.

Keywords: Dividend Policy, Equity Prices, Market value, Commercial Banks.

Copyright @ 2020: This is an open-access article distributed under the terms of the Creative Commons Attribution license which permits unrestricted use, distribution, and reproduction in any medium for non-commercial use (NonCommercial, or CC-BY-NC) provided the original author and source are credited.

\section{INTRODUCTION}

Conceptually, dividend policy refers to the company's policy which determines the amount of dividends payment and retained earnings for reinvestments while stock price of the firm is the market value that determines shareholders worth regarding capital gain [1]. Dividend policy remains one of the major critical financial decisions often faced by management of corporate organizations like the banking industry. It is a finance management function that determines the proportion of the firm's profit that will be distributed to the shareholders and the proportion that will be retained for further investment.

The policy aims at providing answers to questions such as what proportion of the firm's profit should be distributed to shareholders and what proportion should be retained? Answer to these questions requires a critical investigation of the twin effect of dividend policy on the value of the firm [2].

Dividend policy is a practice adopted by managers in making dividend payout decisions. It entails detailing the amount of cash to be distributed to shareholders and what is to be retained by the firm. Dividend policy contains relevant information about financial well-being, amount and future income of shareholders and helps to maintain market price of the firm's shares [3]. To the manager, investment in the firm is a linear function of dividend policy while to the creditors, dividend policy serves as a measure to evaluate the firm's ability to meet debt obligations [4]. 
Dividend policy remains one of the most controversial issues in corporate finance. The relationship between dividend policy and share price has remained very sharp point of departure among scholars in corporate finance. The intensity of the debate has remained largely unresolved in both global and national pegs of Nigeria. Dividend policy management has the potential to positively or negatively affect stock prices in the capital market that may affect the value of the firm. With the existence of different theories of dividend proposing different views, approaches and values for dividend payment had created a policy deviation for managers who choose dividend policies of their choices leading to fluctuations on stock prices, firm values, and corporate failures.

The age-long debate on the relationship between dividend policy and the value of the firm rages on and dates back to Walter and the "Bird in Hand" theory in 1928, Gordon [5] and the dividend relevance hypotheses of Miller and Modigliani [6] and that of dividend irrelevance hypotheses which have presented a challenge to academicians and practitioners alike.

Existing finance literatures have attempted to provide answers to questions on divided policy and harmonize the theories but mystery still shrouds the dividend policy decisions of corporate organizations in general and Nigerian quoted commercial banks in particular [7].

The consideration of the impact of dividend policy on the market value of quoted commercial banks in Nigeria is imperative based on the various reforms in the sector aimed at repositioning the industry to be an active player in the global financial market. Answering hitherto unanswered questions such as "does dividend policy impact stock price of quoted commercial banks in Nigeria?" and if it does, to what extent? Can corporate managers utilize this impact in taking dividend policy decisions that will enhance shareholders' wealth maximization and the market value of such banks? This study will in addition to the above, help investors in learning how to optimize their returns on investment and highlight portfolio planning strategies and appraise the funding of capital market in Nigeria as banking sector equities are the most active and most traded according to stock market reports. Again it will also ascertain the application of theories underlying the impact of dividend policy and stock price.

Furthermore, there is the problem associated with the fact that empirical studies on the effect of dividend policy on the stock prices of quoted commercial banks in Nigeria have not reached a definite conclusion. For instance, the information content of dividend as it relates to stock price is very trivial [8-10]. And also, the reports on dividend information that convey beyond already reflected earnings may also affect stock prices. Thus, these lacks of clear-cut empirical findings stimulates this study.

\section{THE STUDY OBJECTIVES}

The broad objective of this study to is ascertain dividend policy impact on market value of quoted commercial banks in Nigeria within 2004-2018 respectively. However, the study target objectives are:

- To determine the effect of dividend payout ratios on the equity/stock prices of quoted commercial banks in Nigeria

- To determine the impact of retention ratio on equity/stock prices of quoted commercial banks in Nigeria.

- To ascertain the impact of dividend yield on the equity/stock prices of quoted commercial banks in Nigeria.

\section{RESEARCH HYPOTHESES}

In line with set objectives in the study the research hypotheses will be formulated in the null form as depicted:

- $\mathbf{H o}_{1}$ : There is no significant impact of dividend payout ratios on equity/stock prices of quoted commercial banks in Nigeria.

- $\quad \mathrm{Ho}_{2}$ : Retention ratio has no significant impact on s equity/stock prices of quoted commercial banks in Nigeria.

- Hoz: Dividend Yield has no significant impact on equity/stock prices of quoted commercial banks in Nigeria.

The rest of this study will reflect: Review of related literatures, employed methodology, data analysis and summary, concluding remarks with recommendations.

\section{REVIEW OF RELATED LITERATURES CONCEPTUAL UNDERSTANDING Dividend Policy}

Dividend policy involves the determination of the payout policy that management follows in determining the size and pattern of cash distributions to shareholders over time [13]. It refers to a company's policy which determines the amount of dividend payments and the amount of retained earnings for reinvesting in new projects. This policy is related to dividing the firm's earnings between payments to shareholders and reinvestment in new opportunities.

In corporate finance, one of the most important decisions in respect to shareholders is dividend policy. It entails what proportion of profit must be paid to shareholder and what proportion must be returned to the business? Providing possible answers to these questions, managers must consider which dividend policy will lead to maximization of shareholder's wealth and the amount required for reinvestment, and 
also to consider the impact of their decision on stock's prices.

Dividend is also related to capital structure indirectly and different dividend policies may require policies which form basis of the study. It involves the determination of the payout policy that management follows in determining the size and pattern of cash distribution to shareholders over time [11]. According to Botha [12], the investment, financing and dividend decisions are interdependent and must be resolved simultaneously. A combination of these policy decisions should theoretically maximize shareholders' wealth.

In the valuation process, Lease et al., [13] state that the value of an asset, real or financial, is determined by the size, timing, and risk of expected future cash flows that accrue to the owner of the asset. Similarly, markets value share prices that are based on expected dividends and the risk attached to ownership of such shares [13]. For the shareholders this implies that the value of a share is the selling price of the share plus any dividends payable whilst owning the share. Share price is therefore a key determinant of the value of the firm. If dividends are the key indicators of share prices and the share prices are the key indicator of the firm value, it stands to reason that to maximize shareholders' wealth; shareholders should be afforded the highest combination of dividends and the changes in share prices.

A valuation model that captures the market risk of a firm is called capital asset pricing model (CAPM). According to Kaen [14], to determine an investor's required rate of return using CAPM, market risk is captured by statistic called beta $(\beta)$ that measures how companies stock prices moves relative to the market as a whole. In order to create excess cash flows, management has to invest in projects that have positive net present values (NPV's). This is known as applying the NPV rule. The excess cash flows generated by positive NPV projects result in higher earnings.

\section{TYPES OF DIVIDEND POLICIES \\ Residual Policy}

This policy spelt out that firms should pay dividends from the earnings left after financing all positive NPV projects. In this policy, the main concern of the mangers is to invest more and more, and in this case dividend policy becomes irrelevant. Firms adopt this type of policy because they mostly rely on internally generated funds and are not willing to raise new capital for saving floatation and other costs associated with issuing debt and the managers think that high retention results to more growth to the company which conforms to maximization of shareholders' wealth as the firm's is enhanced.

\section{Constant Payout Residual Dividend Policy}

In this type of policy, firms pay a fixed percentage of its earnings to the shareholders each year called dividend payout ratio. Thus, it's calculated by dividing yearly dividend per share by firm's earnings per share. If the earnings of the firm reduce or firm faces shocks in any year, the dividends will also be reduced or diminished. Firms rarely select this dividend policy type due to its inherent shortfall.

\section{Smooth Residual Dividend Policy}

Many firms adopt this type of policy. In this type of dividend policy, firms pay fixed amount of dividend to shareholder each year. Firms don't cut dividend after announcement is made. Firms using this policy only increase the dividends when they are sure.

\section{DETERMINANTS OF DIVIDEND PAYOUT DECISION}

The following are major determinants of dividend payout decision:

\section{Corporate Profitability}

Corporate profitability has long been regarded as the primary indicator of a firm's capacity to pay dividends. Linter [15] and Baker et al., [16] indicate that the dividend payment pattern of a firm is influenced by the current year's earnings and previous year's dividends. Baker et al., [16] found that the anticipated level of future earnings is the determinant of dividend payment. Pruitt and Gitman [17] in their study report that current and past years' profits are important factors in influencing dividend payments. Baker and Powell [18] concluded from their survey of NYSE-listed firms that dividend determinants are industry specific and anticipated level of future earnings is the major determinant. Amidu and Abor [19] found a positive relationship between corporate profitability and dividend payout ratios. Anil and Kapoor (2008) indicate that profitability has always been considered as a primary indicator of dividend payout ratio. Brook et al., [20] explicitly stated that there is no reason to believe that corporate dividend policy is driven by a single goal.

\section{Cash Flow}

The cash flow position of a firm is an important determinant of dividend payouts. A poor liquidity position means less generous dividend payout due to shortage of cash. Alli et al., [21] argue that dividend payments depend more on cash flows, which reflect the company's ability to pay dividends than on current earnings which are less influenced by accounting practices. They argued that current earnings do not really reflect the firm's ability to pay dividends. Amidu and Abor [19] found a positive relationship between cash flow and dividend payout ratios. Anil and Kapoor [22] also indicate that cash flow is an important determinant of dividend payout ratio. 
Tax

Tax-adjusted models presume that investors require and secure higher expected returns on shares of dividend-paying. The consequence of tax-adjusted dividend policy decision is the division of investors into dividend tax clientele. Modigliani [23] argued that the clientele effect is responsible for the alterations in portfolio composition. Masulis and Truman's [24] model predicts that investors with different tax liabilities will not be uniform in their ideal firm dividend policy. They conclude that as tax liability decreases the preference that dividend payment also increases. Tax-adjusted model assumes that investors maximize after-tax income. As far back as 1967, Farrar and Selwyn [25] concluded that in a partial equilibrium framework, individual investors choose the amount of personal and leverage and also whether to receive corporate distributions as dividends or capital gain. Amidu and Abor [19] found a positive relationship between tax and dividend payout ratio.

\section{Sales Growth}

Sales growth may impact on dividend payout ratio. Dividend payout levels are not totally decided after a firm's investment and financing decisions have been made rather, the dividend decision is taken along investment and financing decisions.

Partington [26] pointed out firm's target payout ratios for paying dividends, and the extent to which dividends are determined are independent of investment policy. Huggins [27] shows a direct link between growth and financing needs of a firm. Rapidly growing firms require external financing because working capital needs normally exceed the incremental cash flows from new sales. In an earlier paper Higgins [28] argues that payout ratio is negatively related to a firm's need for funds to finance growth opportunities. Rozeff [29], all shows a significantly negative relationship between historical sales growth and dividend payout.

\section{Market to Book Ratio}

Market to book ratio reflects the market view of the value of equity in comparison to what shareholders have contributed to the firm since the day it was established.

Pmran and Pointon [30] points that market to book ratio is an important factor that influence dividend payout ratio, and Amidu and Abor [19] found a negative relationship between market to book ratio and dividend payout ratios.

\section{Debt to Equity Ratio}

The debt to equity ratio is a financial ratio that indicates the relative proportion of equity and debt used to finance a company's assets. This ratio is also known as risk, gearing or leverage. Pruitt Gitman [17] indicates that risk affects firms' dividend policy. Firms with high growth rates and high dividend payout ratios utilize debt financing and firms with high leverage compared to their respective industry. Dhillon [31], however, found conflicting evidence for the relationship between dividend payout ratios and leverage.

Rozeff [32], Lloyd et al., [33] and Collins et al., [34] found statistically significant and negative relationship between firm's risk and the dividend payout ratios. Their findings suggest that firms having a higher level of risk will pay out dividends at lower rate. D'Souza [35] also finds statistically significant and negative relationship between risk and dividend payout.

\section{THEORETICAL FRAME WORK}

This study hinges on dividend relevance theory and efficient market hypothesis.

\section{Dividend Relevance Theory}

This theory is associated with Gordon's, John Linter, James Walter and Richardson. According to them, dividend policy has a positive impact on the firm's position in the stock market. That is, higher dividend will increase the value of stock whereas low dividend will reduce the firm's stock value.

Gordon's [36] suggested a valuation models relating the market value of the stock with dividend policy. Gordon studied dividend policy and market price of the shares and proposed that the dividend policy of firms affects the market value of stocks even in the capital market. He stated that investors may prefer present dividend instead of future capital gains because the future situation is uncertain even if in perfect capital market. Indeed, he explained that many investors may prefer dividend in hand in order to avoid risk related to future capital gain. He also proposed that there is a direct relationship between dividend policy and market value of share even if the internal rate and the required rate of return will be the same. That is, the share price of firm is subordinate of discounted flow of future dividends [36].

\section{Efficient Market Hypothesis}

Efficient Market Hypothesis (EMH) asserts that in an efficient market, prices at all times fully reflect all available information that is relevant to their valuation [37]. The efficiency of stock markets has been a major area of research in financial economics, particularly as it pertains to stock markets of developing economies [38]. This is because of the implication of market efficiency to the functioning of the capital market; especially as it concerns investors' and thus stimulation of investor's interest in market activities. It is believed that the behaviour of stock prices is explained by the behaviour of investors Inegbedion [39]. 
Efficient Market Hypothesis (EMH) argues that competition between investors seeking abnormal profits drives prices to their fair value. This implies that prices should incorporate information into prices that determines its level of efficiency.

Adewole and Maduegbuna [40] Made a remarkable effort to apply econometric techniques of modeling the prediction of stock prices in a bid to demonstrate that the market fluctuates are essentially unpredictable. Brummelhuis [41], have argued that there are long-term pattern in stock prices with several years of upswing followed by more sluggish periods, according to Fama [37], a stock market where successive price changes in individual security is independent by definition (a random walk market). Specially, stock prices following a random walk imply that the price changes are as independent of one another as the gains and losses [42].

The independence assumption of the random walk hypothesis is valid as long as knowledge of the past behavior of the series of price changes cannot be used to increase expected gains [43]. More specifically, if successive price changes for a given security are independent, then there is no problem in timing purchases and sales of the security. A simple policy of buying and holding the security will be as good as any more complicated mechanical procedure for timing purchase and sales [37, 44]. Fama [45] stated that the sufficient but not necessary conditions for efficiency are:

- There are no transaction costs in trading securities;

- All information is costless and available to all market participants, and

- All agree on the implication of current information for the current price and distribution of future prices of each security.

The efficient market Hypothesis (EMH) can be specially defined with respect to the information item available to market participants. Fama [45] classified the information items into three levels depending on how quickly the information is impounded into prices:
1. Weak Form Efficiency
2. Semi Strong Form Efficiency
3. Strong From Efficiency

\section{Weak Form Efficiency}

In weak-form efficiency, future prices cannot be predicted by analyzing prices from the past. Excess returns cannot be earned in the long run by using investment strategies based on historical share prices or other historical data Lulia [46].

Analytical techniques will not be able to consistently produce excess returns, though some forms of fundamental analysis may still provide excess returns. Share prices exhibit no serial dependencies, meaning that there are no "patterns" to asset prices. This implies that future price movements are determined entirely by information not contained in the price series. Hence, prices must follow a random walk. This soft EMH does not require that prices remain at or near equilibrium, but only that market participants cannot be able to systematically profit from market inefficiencies. However, while EMH predicts that all price movement is random, many studies have shown a marked tendency for the stock markets to trend over time periods of weeks or longer and that, there is a positive correlation between degree of trending and length of period studied. Various explanations for such large and apparently non-random price movements have been promulgated.

\section{Semi Strong Form Efficiency}

Semi strong form efficiency implies that share prices adjust to publicly available new information very rapidly and in an unbiased fashion, such that no excess returns can be earned by trading on that information. Semi strong form efficiency implies, neither fundamental analysis nor technical analysis techniques will be able to reliably produce excess returns. To test for semi-strong-form efficiency, the adjustments to previously unknown news must be of a reasonable size and must be instantaneous. To test for this, consistent upward or downward adjustments after the initial change must be looked for. If there are any such adjustment it would suggest that investors had interpreted the information in a biased fashion and hence in an inefficient manner Olowe [47].

\section{Strong Form Efficiency}

In strong form efficiency, share prices reflect all information, public and private, and no one can earn excess returns. If there are legal barriers to private information becoming public, as with insider trading laws, strong form efficiently is impossible, except in the case where the laws are universally ignored.

To test for strong form efficiency, a market needs to exist where investors cannot consistently earn excess returns over a long period of time. Even if some money managers are consistently observed to beat the market, there is no refutation even if it's been followed with hundreds of thousands of money managers worldwide [48].

\section{EMPIRICAL REVIEW}

Baskin [1] examined the association between dividend policy and stock price volatility. He added, some control variables for examining the association between share price volatility and dividend yield. These control variables are earning volatility, firm's size, debt and growth. The variables do not only have clear effect on stock price volatility but they also not affect dividend yield. But earning volatility has effect on share price volatility and it affects the optimal dividend policy for corporations. Moreover, with assumption that the 
operation risk is constant and the level of debt might have positive effect on dividend yield.

Nazir et al., [49] used 73 firms listed in Karachi Stock Exchange (KSE0) as sample and studied the relationship between share price volatility and dividend policy for the period of 2003-2008. They applied fixed effect and random effect models on panel data. They reported that share price volatility has significant negative association with dividend yield and dividend payout. They also reported that size and leverage have non-significant effect on share price volatility.

Suleitility et al., 2011 studied the association of dividend policy with share price volatility in Pakistan. They extracted data from Karachi Stock Exchange regarding five important sectors for the period of 2005 to 2009 . They used multiple regressions model for their analysis. Contrary to Baskin [1] results, their findings showed that share price volatility has significant positive relationship with dividend yield. They also reported that share price volatility has significant negative relationship with growth.

Hussainey et al., [50] examined the relationship between share price volatility and dividend policy in UK. They selected 123 English companies and the period of their study was from 1998 to 2007. Their work was Similar to Baskin [1] which they used multiple regression analysis for exploring the relationship of share price with dividend yield and dividend payout ratio. They added size, level of debt, earning volatility and level of growth as control variables to their model. Their study found a significant negative relationship between share price volatility and payout ratio. They also found a negative relationship between share price volatility and dividend yield. Their findings discovered that the payout ratio is the predominant determinant of the share price volatility and size and debt have the strongest relationship with share price volatility amongst control variables.

Amidu and Abor [19] conducted a study on the determinants of dividend policy by using panel data of 20 firms listed in Ghana Stock Exchange. Dividend payout ratio was taken as dependent variable. They proved that dividend payout was mostly dependent on the net earnings of the firms and also those firms with high liquidity pay high dividends. The association of dividend payout with risk is negative in nature.

Rashid and Rehman [51] conducted a study in Bangladesh. They took 104 non-financial firms for a period of 1999 to 2006. They found a positive but nonsignificant relationship between dividend yield and stock price volatility in the capital market of Dhaka Stock exchange. They also found that there is no considerable relation between declaration of earnings and the stock prices as seen in the developed capital markets. The insignificant relationship between stock price volatility and dividend policies may be as a result of inefficient capital market of Bangladesh or due to the fact that majority of shares held by dominant shareholders also working in the companies.

In summary, the related reviewed literatures pointed out to the fact that corporate profitability, cash flow, tax, sale-growth, market to book ratio, and debt to equity ratio may impact upon the dividend policy. Previous researchers concentrated on the determinants of standard ratio of dividend to earnings, or the standard dividend payout ratio and that of dividend yield. This study examines the determinants of dividend policy to also include retention ratio whereby the denominator of the ratios is the quoted commercial banks in Nigeria that has relatively highest number of stocks traded in the Nigerian Stock Exchange (NSE).

\section{METHODOLOGY}

This study uses quasi experimental research design approach for the data analysis. This approach combines theoretical consideration (a-priori criterion) with the empirical observation and extract maximum information from the available data. It enables us therefore to observe the impact of explanatory variables on the explained variable.

\section{The Study Population}

The population of this study is on the current existing twenty one (21) banks in Nigeria. However, the sample size is restricted to only existing quoted commercial banks in Nigerian Stock Exchange (NSE).

\section{Nature and Sources of Data}

Data required for the estimation and testing of the hypotheses formulated in line with set objectives in this study are: Dividend payout ratio (DPR), Retention ratio (RTR) and Dividend yield (DVY) as proxy for the impact variable (Dividend Policy) while Equity/Stock price of quoted commercial banks in Nigeria (EQP) is used as the explained variable (Market value of quoted commercial banks in Nigeria) for the period under study.

The data for this study are secondary data sourced from the Central Bank of Nigeria (CBN) Statistical Bulletin, 2018, Nigerian Stock Exchange (NSE) Fact file, 2018 and Financial Statements of the quoted commercial banks in Nigeria on current year.

- Equity/Stock Price: The stock price of firms according to theories is the market value of the firm which is the function of the internal and the external environment. Empirical evidence has been in support of the relevance theory of Gordon, therefore dividend policy as component of internal financial policy can affect the stock price of quoted commercial banks in Nigeria. This study used end of year trading prices for quoted commercial banks 
in Nigeria sourced from Nigerian Stock Exchange (NSE) Fact file, 2018.

- Dividend Payout Ratio: This refers to the proportion of firms' profit that is distributed to the shareholders as return on investment. According to the tradeoff theory, higher dividend ratio affects the capital structure, investment decision, cost of capital and of the firm and the market value of the firm.

- Retention Ratio: This is simply the proportion of capitalized earnings expressed in percentage. It is the inverse proportion of payout ratio. This is a crucial part of financial decision making by managers.

- Dividend Yield: This presents how much cash flow one receives from each amount invested in equity of a firm. For investors with minimum benchmark or expected streams of cash flow, dividend yield of a given share price shows if the share price is efficient with respect to its yield [52]. As a measure of efficiency it is expected to have a direct effect on the market value.

\section{DATA ANALYSIS}

The following econometric techniques shall be employed for the analysis of the data-set and the estimation of the model: Augmented dickey-fuller (ADF) test, Johansen Co-integration test Model Stability test and Error Correction Mechanism (ECM).

\section{Model Specification}

Based on the objectives of the study, the functional model is specified as follows:

$E Q P=F(D P R, R T R, D V Y)$ 1
Where it is empirically stated as:

$\mathrm{EQP}=$ Equity/Stock Price of Nigerian Quoted

Commercial Banks in Nigeria

DPR $=$ Dividend Payment Ratio

RTR $=$ Retention Ratio

DVY $=$ Dividend Yield

The explicit form of econometric specification of the Linear multiple regression model is given as:

$E Q P=a_{0}+a_{1} D P R_{t}+a_{2} R T R_{t}+a_{3} D V Y_{t}+U e_{t}$

Where:

$\mathrm{a}_{0}=$ Regression intercept

$a_{1} \ldots a_{3}=$ The slope or coefficients to be estimated.

Uet $=$ The stochastic error disturbance term. It account for other variables not captured in the model.

\section{A-priori Expectation}

We expect that all the explanatory variable coefficients should be greater than zero and have a predictive ability on the explained variable (market value of quoted commercial banks in Nigeria). i.e: $a_{1}>0$ $\mathrm{a}_{2}>0 \mathrm{a}_{3}>0$

\section{Decision Rule}

Inference about the hypotheses is made by considering the t-statistics outcome in absolute terms and the critical values (probabilities) associated with individual variables. In this study the decision rule is to reject the null hypotheses (H0) if the t-statistics outcome is greater than critical values (probabilities) at $5 \%$ level of significance.

\section{ANALYSIS AND INTERPRETATION OF DATA}

Table-1: Unit Root Test Results

\begin{tabular}{|l|l|l|l|}
\hline Variables & ADF t-Statistics & Critical Value @ 5\% & Order of Integration \\
\hline EQP & -2.719436 & -1.982344 & $1(1)$ \\
\hline DPR & -2.985588 & -1.970978 & $1(1)$ \\
\hline RTR & -2.985588 & -1.970978 & $1(1)$ \\
\hline DVY & -4.487996 & -1.974028 & $1(1)$ \\
\hline
\end{tabular}

Source: E-view 9 output

Table-1 shows unit root test results for specified variables in the study. The results revealed stationarity of variables (integrated) at first difference, symbolized by: 1(1) at 5\% significant level. This implies that variables have no unit root problem. Data are said to have no unit root problem if the test statistics is greater than the critical value in absolute terms. This means that variables employed can be used for meaningful decision making. 
Table-2: Johansen Cointegration Test Results

\begin{tabular}{|c|c|c|c|c|}
\hline \multicolumn{5}{|c|}{ Date: $12 / 09 / 19$ Time: 09:46 } \\
\hline \multicolumn{5}{|c|}{ Sample (adjusted): 20062018} \\
\hline \multicolumn{5}{|c|}{ Included observations: 13 after adjustments } \\
\hline \multicolumn{5}{|c|}{ Trend assumption: Linear deterministic trend (restricted) } \\
\hline \multicolumn{5}{|c|}{ Series: EQP DPR DVY } \\
\hline \multicolumn{5}{|c|}{ Lags interval (in first differences): 1 to 1} \\
\hline \multicolumn{5}{|c|}{ Unrestricted Cointegration Rank Test (Trace) } \\
\hline Hypothesized & & Trace & 0.05 & \\
\hline No. of CE(s) & Eigenvalue & Statistic & Critical Value & Prob.** \\
\hline None * & 0.902114 & 59.98333 & 42.91525 & 0.0005 \\
\hline At most $1 *$ & 0.806480 & 29.77202 & 25.87211 & 0.0155 \\
\hline At most 2 & 0.476793 & 8.421125 & 12.51798 & 0.2192 \\
\hline \multicolumn{5}{|c|}{ Trace test indicates 2 cointegrating eqn(s) at the 0.05 level } \\
\hline \multicolumn{5}{|c|}{$*$ denotes rejection of the hypothesis at the 0.05 level } \\
\hline \multicolumn{4}{|c|}{ **MacKinnon-Haug-Michelis (1999) p-values } & \\
\hline
\end{tabular}

Source: E-view 9 output.

Table-2 evidenced the Johansen cointegration test result that indicates the existence of two cointegrating long run relationship among variables employed in this study. We arrive at this conclusion by comparing the trace statistic against the Critical Values at $5 \%$ significant level.

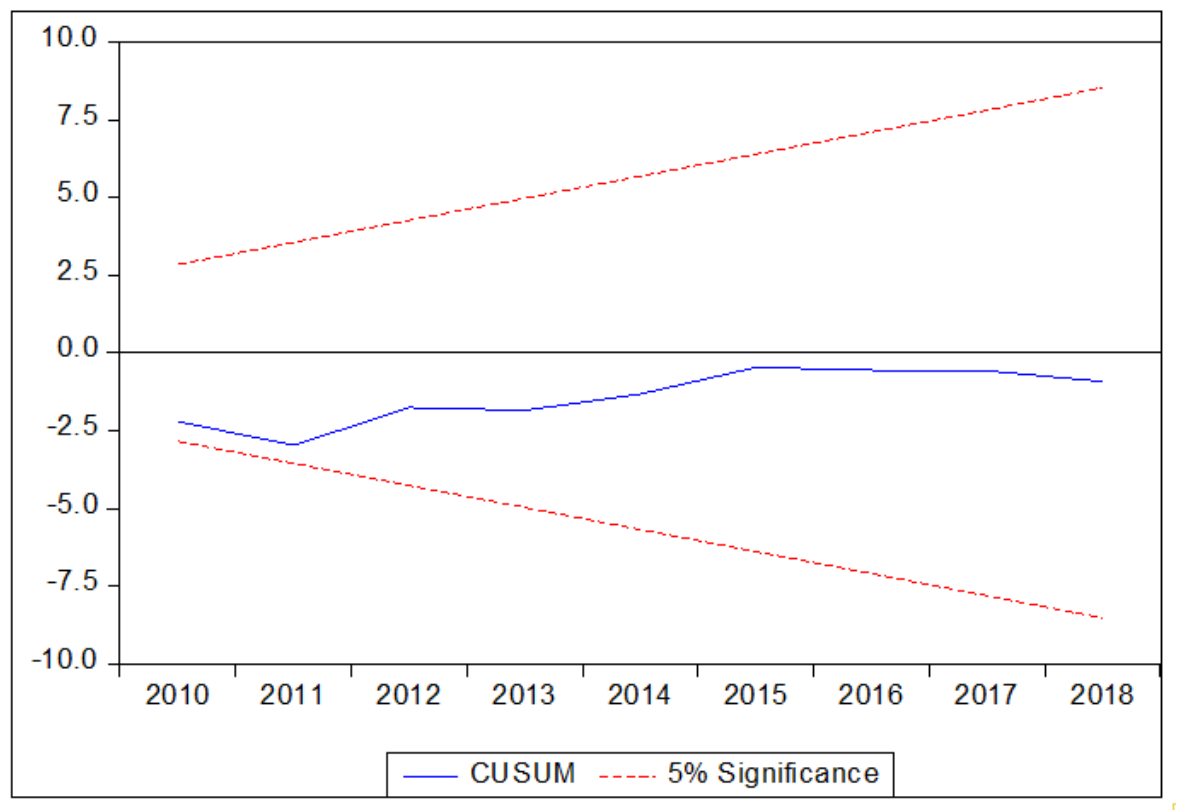

Graph-1: Model Stability Test

Source: Author's computation: E-view 9 output.

Graphs-1 for test of stability of the model shows that all variable used in the model are valid. This is because the blue line starts from the point of near zero and increases gradually to fluctuate between the two red lines given. Therefore, we can run a regression on them for individual parameter estimate. 
Table-3 Parsimonious Error Correction Model (ECM)

\begin{tabular}{|c|c|c|c|c|}
\hline \multicolumn{5}{|c|}{ Dependent Variable: $\mathrm{D}(\mathrm{EQP})$} \\
\hline \multicolumn{5}{|c|}{ Method: Least Squares } \\
\hline \multicolumn{5}{|c|}{ Date: 12/09/19 Time: 11:08 } \\
\hline \multicolumn{5}{|c|}{ Sample (adjusted): 20052018} \\
\hline \multicolumn{5}{|c|}{ Included observations: 14 after adjustments } \\
\hline Variable & Coefficient & Std. Error & t-Statistic & Prob. \\
\hline $\mathrm{C}$ & 3.328222 & 0.930762 & 3.575803 & 0.0074 \\
\hline $\mathrm{D}(\mathrm{DPR})$ & 4.152515 & 1.804549 & 2.301137 & 0.0328 \\
\hline $\mathrm{D}$ (RTR) & -4.041634 & 1.569131 & -2.575715 & 0.0299 \\
\hline D(DVY) & 6.000505 & 2.018846 & 2.972245 & 0.0036 \\
\hline ECM(-1) & -0.750954 & 0.332926 & -2.255618 & 0.0393 \\
\hline R-squared & 0.639713 & \multicolumn{2}{|c|}{ Mean dependent var } & 1.264286 \\
\hline Adjusted R-squared & 0.435141 & \multicolumn{2}{|c|}{ S.D. dependent var } & 10.23310 \\
\hline S.E. of regression & 8.343957 & \multicolumn{2}{|c|}{ Akaike info criterion } & 7.353405 \\
\hline Sum squared resid & 626.5945 & \multicolumn{2}{|c|}{ Schwarz criterion } & 7.581640 \\
\hline Log likelihood & -46.47384 & \multicolumn{2}{|c|}{ Hannan-Quinn criter. } & 7.332278 \\
\hline F-statistic & 2.638253 & \multicolumn{2}{|c|}{ Durbin-Watson stat } & 2.108184 \\
\hline Prob(F-statistic) & 0.000414 & & & \\
\hline
\end{tabular}

Source: Author's computation: E-view 9 output

Table- 3 above revealed the extent of dividend policy impact on market value of quoted commercial banks in Nigeria. The objective of the error correction term is to determine the extent to which the variables have shifted from equilibrium and the speed of adjustment. The conventional rule according to theory is that the model must have a negative coefficient. From Table-3, it shows that the model has shifted from equilibrium and it will take $75 \%$ speed to adjust to equilibrium. ECM coefficient of -0.750954 indicates that ECM is well specified and the diagnostic statistics are good. The negative sign indicates the short run adjustment of the explanatory variables to the explained variable. The $75 \%$ speed of adjustment towards equilibrium implies that $75 \%$ of disequilibrium caused by exogenous shocks or short run fluctuations in the previous period is corrected in the current year.

Using the a priori criteria of evaluating the parameters, all the variables including the constant (DPR, RTR, DVY and $\operatorname{ECM}(-1)$ ) met a priori expectations hence fulfilling the economic criterion of the model.

The results also show that retention ratio (RTR) is non-linear (negative) and statistically significant to Equity/Stock prices (EQP) of quoted commercial banks in Nigeria, while dividend payout ratio (DPR) and dividend yield (DVY) are linear (positive) and statistically significant to Equity/Stock prices (EQP) of quoted commercial banks in Nigeria both in short and in the long run. Furthermore, the results of the test of the overall significance of the model using F-statistics shows that the entire model is statistically significant. We arrive at this conclusion because the F-statistics is greater than the F-probability. Coefficients of determination $\left(\mathrm{R}^{2}\right)$ indicate that approximately $64 \%$ of total variation in EQP is explained by the explanatory variables in the model.
This means that the model is of good fit. Finally, the Durbin-Watson statistics of 2.108184 is within the acceptance region thus, indicating the absence of first order autocorrelation.

\section{TEST OF HYPOTHESES}

The t-statistics output in table 1.3 reveals that dividend payout ratio (DPR), retention ratio (RTR) and dividend yield (DVY) have t-statistic of: 2.301137, 2.575715 and 2.972245 with an associated probabilities value of: $0.0328,0.0299$ and 0.0036 respectively, which is less than $5 \%$ significant level. Hence the null hypotheses are rejected. This implies that dividend payout ratio, retention ratio and dividend yield have significant impact on equity/stocks prices of quoted commercial banks in Nigeria within the range of study.

\section{DISCUSSIONS OF FINDINGS}

The issue of dividend policy and the market value of quoted firms has long been a debate amongst scholars in the field of corporate finance. The broad objective of this study is to determine Nigerian context of dividend policy impact on the market value of quoted commercial banks. From the error correction model (ECM) results, dividend payout ratio has positive and significant relationship with equity prices of the quoted commercial banks in Nigeria. The positive co-efficient of 4.152515 indicates that a $1 \%$ increase in dividend payout Ratio will lead to $4 \%$ increase in Equity Prices of quoted commercial banks in Nigeria within the range of study.

In consonance, the positive coefficient of dividend yield of 6.000505 also indicates positive relationship between dividend yield and equity prices of quoted commercial banks in Nigeria. This relationship implies that $1 \%$ increase in dividend yield by quoted commercial banks in Nigeria will attract more investors to invest in its equities by $5 \%$. However, retention ratio 
is contrary to findings of dividend payout ratio and dividend yield with non-linear significant relationship with equity prices of quoted commercial banks in Nigeria within same study range. This implies that quoted commercial banks in Nigeria percentage increase in retention ratio will reduce its equity prices by $4 \%$ also.

This finding confirms the apriori expectations and that of the opinion of Gordon's on relevance theory of dividend policy but contradict the opinions of Miller and Modigliani on dividend irrelevance theory that indicates firms' declaration and payment of dividends to not have little or absolute impact on equity prices and to the value of the firm. The study findings also contradict the empirical findings of Hussainey et al., [50] that examined the relationship between share price volatility and dividend policy in UK, with significant negative relationship between share price volatility and payout ratio and dividend yield.

\section{SUMMARY，CONCLUING RENARKS WITH RECOMMENDATIONS}

This study examined dividend policy impact on market value of quoted commercial banks in Nigeria within 2004-2018 as a study range. The study was portioned in different sections meticulously towards achieving targeted objectives predicted upon stated null forms of hypotheses with particular interest to proxy the impact variable (dividend policy) as dividend payout ratio, retention ratio and dividend yield specified with acronyms as: DPR, RTR and DVY, while market value of quoted commercial banks were proxy as its equity/stock prices. From the empirical findings of the study, we are constrained to conclude as follows:

- Dividend payout ratio has a linear and significant impact on equity prices of quoted commercial banks in Nigeria within the given study range

- Retention ratio has a non-linear and significant impact on equity prices of quoted commercial banks in Nigeria within the given study range
- Dividend yield also has a linear and significant impact on equity prices of quoted commercial banks in Nigeria within the given study range.

Therefore, dividend policy has a collective significant impact on the market value of quoted commercial banks in Nigeria with varied relationship among employed variables. And as such, the study recommends that, Central Bank of Nigeria $(\mathrm{CBN})$, Securities and Exchange Commission (SEC) and the established Financial Regulatory council (FRC) to step up regulatory oversight functions to ensure transparency, business ethics and good corporate governance in the banking industry particularly quoted commercial banks in Nigeria. This will help curtail the anxiety of investors and relatively reduce the practices of declaration of huge paper profits, insider trading, manipulation of stock prices and other nefarious acts.

We also stand to recommend to Nigerian Stock Exchange (NSE) to profess a consolidated awareness program to educate the investing public on fundamental of investing in the capital market and their right as shareholders to claiming their dividend as at when due. And that Stockbroker should ensure proper documentation of investors in respect to mailing addresses, phone numbers and accounts numbers for direct transfers of dividends.

Finally, the findings in this study has established empirically and scientifically a strong relationship between dividend policy and equity price of quoted commercial banks in the Nigerian Capital Market and therefore confirms that dividend policy is very relevant to firms' value. Managers of banks are therefore provided useful information to effectively and professionally manage their firms' dividend policy having at the back of their minds the impact this has on their equity prices for banks sustainability.

\section{APPENDIX}

Data used in the study

\begin{tabular}{|l|l|l|l|l|}
\hline YEARS & EQP\% & DPR\% & RTR\% & DVY\% \\
\hline 2004 & 3.1910 & 22.48 & 77.52 & 32.54 \\
\hline 2005 & 3.2233 & 25.54 & 74.47 & 39.72 \\
\hline 2006 & 4.4416 & 20.93 & 79.07 & 34.26 \\
\hline 2007 & 7.7607 & 22.58 & 77.42 & 25.62 \\
\hline 2008 & 4.2090 & 18.78 & 81.22 & 80.13 \\
\hline 2009 & 2.7872 & 10.14 & 89.86 & 57.54 \\
\hline 2010 & 3.3150 & 8.98 & 91.02 & 41.24 \\
\hline 2011 & 2.7743 & 9.57 & 90.43 & 53.04 \\
\hline 2012 & 3.7577 & 16,61 & 83.39 & 46.33 \\
\hline 2013 & 5.5310 & 17.73 & 82.27 & 44.22 \\
\hline 2014 & 5.2500 & 17.2 & 82.8 & 46.83 \\
\hline 2015 & 3.9241 & 16.16 & 83.84 & 59.25 \\
\hline 2016 & 4.8622 & 17.6 & 82.4 & 50.59 \\
\hline 2017 & 4.9975 & 20.44 & 79.58 & 19.68 \\
\hline 2018 & 3.4838 & 21.49 & 78.51 & 31.6 \\
\hline
\end{tabular}


Peter E. Ayunku \& Tonye Richard Apiri; Saudi J Bus Manag Stud, March., 2020; 5(3): 181-195

Source: Central Bank of Nigeria (CBN) Statistical Bulletin, 2018, Nigerian Stock Exchange (NSE) Fact File, 2018 and Financial Statements of the Quoted Commercial Banks in Nigeria on current year.
Note: $\mathrm{EQP}=$ Equity/Stock Prices of Quoted Commercial Banks in Nigeria, DPR=Dividend Payout Ratio, RTR=Retention Ratio and DVY=Dividend Yield.

\section{ADF Test for EQP}

\begin{tabular}{|c|c|c|c|c|}
\hline \multicolumn{4}{|c|}{ Null Hypothesis: D(EQP) has a unit root } & \\
\hline \multicolumn{4}{|l|}{ Exogenous: None } & \\
\hline \multicolumn{5}{|c|}{ Lag Length: 3 (Automatic - based on SIC, maxlag=3) } \\
\hline & & & $\mathrm{t}-$ Statistic & Prob.* \\
\hline \multicolumn{3}{|c|}{ Augmented Dickey-Fuller test statistic } & -2.719436 & 0.0121 \\
\hline \multirow[t]{3}{*}{ Test critical values: } & $1 \%$ level & & -2.816740 & \\
\hline & $5 \%$ level & & -1.982344 & \\
\hline & $10 \%$ level & & -1.601144 & \\
\hline \multicolumn{4}{|c|}{ *MacKinnon (1996) one-sided p-values. } & \\
\hline \multicolumn{5}{|c|}{ Warning: Probabilities and critical values calculated for 20 observations and may not be accurate for a sample size of 10} \\
\hline \multicolumn{4}{|c|}{ Augmented Dickey-Fuller Test Equation } & \\
\hline \multicolumn{3}{|c|}{ Dependent Variable: $\mathrm{D}(\mathrm{EQP}, 2)$} & & \\
\hline \multicolumn{3}{|c|}{ Method: Least Squares } & & \\
\hline \multicolumn{3}{|c|}{ Date: 12/09/19 Time: 09:20 } & & \\
\hline \multicolumn{3}{|c|}{ Sample (adjusted): 20092018} & & \\
\hline \multicolumn{4}{|c|}{ Included observations: 10 after adjustments } & \\
\hline Variable & Coefficient & Std. Error & t-Statistic & Prob. \\
\hline $\mathrm{D}(\mathrm{EQP}(-1))$ & -1.586412 & 0.583361 & -2.719436 & 0.0347 \\
\hline $\mathrm{D}(\mathrm{EQP}(-1), 2)$ & 0.684662 & 0.417901 & 1.638335 & 0.1525 \\
\hline $\mathrm{D}(\mathrm{EQP}(-2), 2)$ & 0.255566 & 0.285434 & 0.895360 & 0.4051 \\
\hline $\mathrm{D}(\mathrm{EQP}(-3), 2)$ & 0.337365 & 0.176457 & 1.911877 & 0.1044 \\
\hline R-squared & 0.817323 & \multicolumn{2}{|c|}{ Mean dependent var } & 1522.840 \\
\hline Adjusted R-squared & 0.725984 & \multicolumn{2}{|c|}{ S.D. dependent var } & 12654.19 \\
\hline S.E. of regression & 6624.028 & \multicolumn{2}{|c|}{ Akaike info criterion } & 20.72397 \\
\hline Sum squared resid & $2.63 \mathrm{E}+08$ & \multicolumn{2}{|c|}{ Schwarz criterion } & 20.84500 \\
\hline Log likelihood & -99.61985 & \multicolumn{2}{|c|}{ Hannan-Quinn criter. } & 20.59120 \\
\hline Durbin-Watson stat & 2.154342 & & & \\
\hline
\end{tabular}

ADF Test for DPR

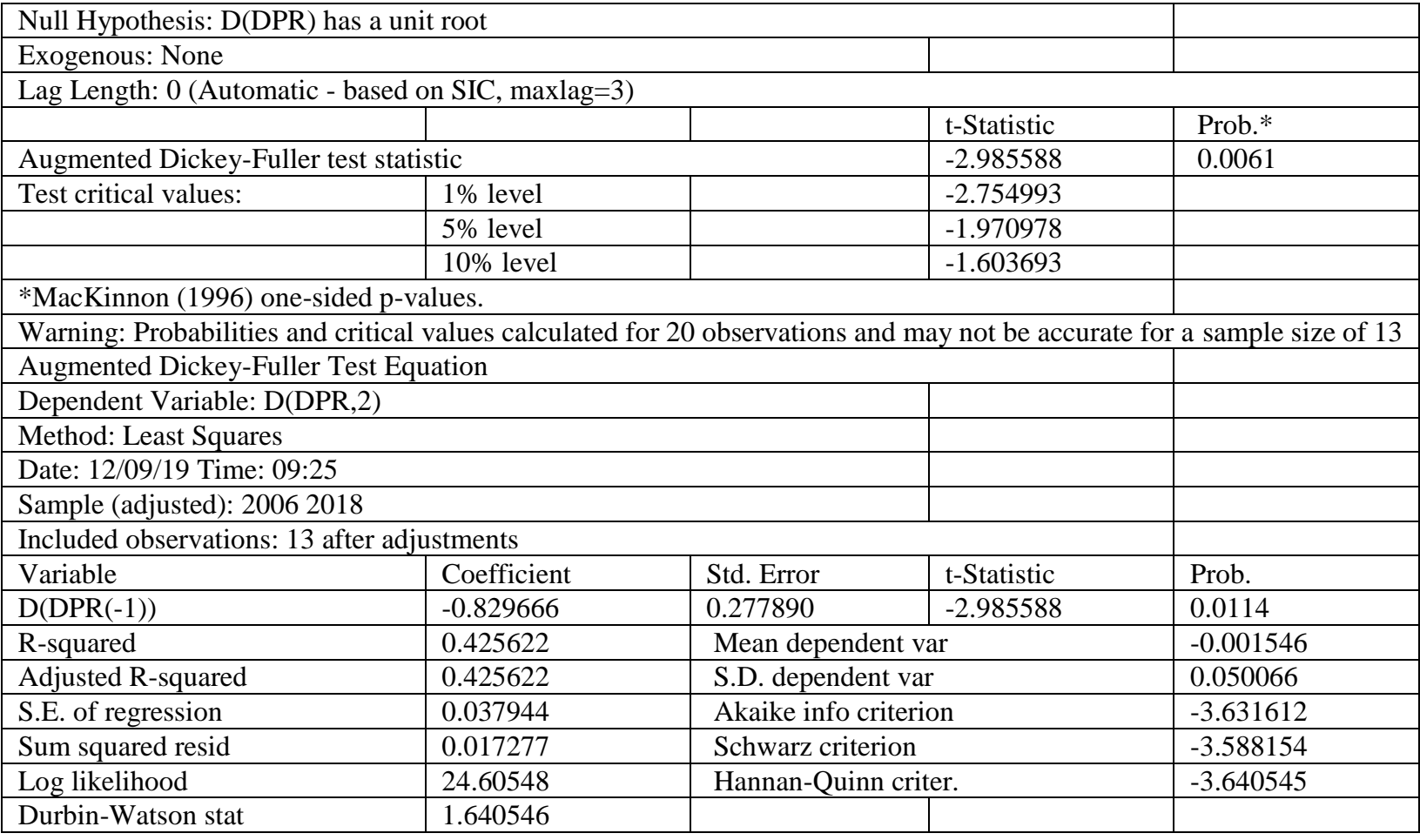




\begin{tabular}{|c|c|c|c|c|}
\hline \multicolumn{5}{|c|}{ ADF Test for RTR } \\
\hline \multicolumn{4}{|c|}{ Null Hypothesis: D(RTR) has a unit root } & \\
\hline \multicolumn{4}{|c|}{ Exogenous: None } & \\
\hline \multicolumn{5}{|c|}{ Lag Length: 0 (Automatic - based on SIC, maxlag $=3$ ) } \\
\hline & & & t-Statistic & Prob.* \\
\hline \multicolumn{3}{|c|}{ Augmented Dickey-Fuller test statistic } & -2.985588 & 0.0061 \\
\hline \multirow[t]{3}{*}{ Test critical values: } & $1 \%$ level & & -2.754993 & \\
\hline & $5 \%$ level & & -1.970978 & \\
\hline & $10 \%$ level & & -1.603693 & \\
\hline \multicolumn{5}{|c|}{ *MacKinnon (1996) one-sided p-values. } \\
\hline \multicolumn{5}{|c|}{$\begin{array}{l}\text { Warning: Probabilities and critical values calculated for } 20 \text { observations and may not be accurate for a sample } \\
\text { size of } 13\end{array}$} \\
\hline \multirow{2}{*}{\multicolumn{5}{|c|}{\begin{tabular}{l|l|}
\multicolumn{2}{|l|}{ Augmented Dickey-Fuller Test Equation } \\
Dependent Variable: $\mathrm{D}(\mathrm{RTR}, 2)$ & \\
\end{tabular}}} \\
\hline & & & & \\
\hline \multicolumn{5}{|c|}{ Method: Least Squares } \\
\hline \multicolumn{5}{|c|}{ Date: $12 / 09 / 19$ Time: $09: 30$} \\
\hline \multicolumn{5}{|c|}{ Sample (adjusted): 20062018} \\
\hline \multicolumn{5}{|c|}{ Included observations: 13 after adjustments } \\
\hline Variable & Coefficient & Std. Error & t-Statistic & Prob. \\
\hline $\mathrm{D}(\mathrm{RTR}(-1))$ & -0.829666 & 0.277890 & -2.985588 & 0.0114 \\
\hline R-squared & 0.425622 & \multicolumn{2}{|c|}{ Mean dependent var } & 0.001546 \\
\hline Adjusted R-squared & 0.425622 & \multicolumn{2}{|c|}{ S.D. dependent var } & 0.050066 \\
\hline S.E. of regression & 0.037944 & \multicolumn{2}{|c|}{ Akaike info criterion } & -3.631612 \\
\hline Sum squared resid & 0.017277 & \multicolumn{2}{|c|}{ Schwarz criterion } & -3.588154 \\
\hline Log likelihood & 24.60548 & \multicolumn{2}{|c|}{ Hannan-Quinn criter. } & -3.640545 \\
\hline Durbin-Watson stat & 1.640546 & & & \\
\hline
\end{tabular}

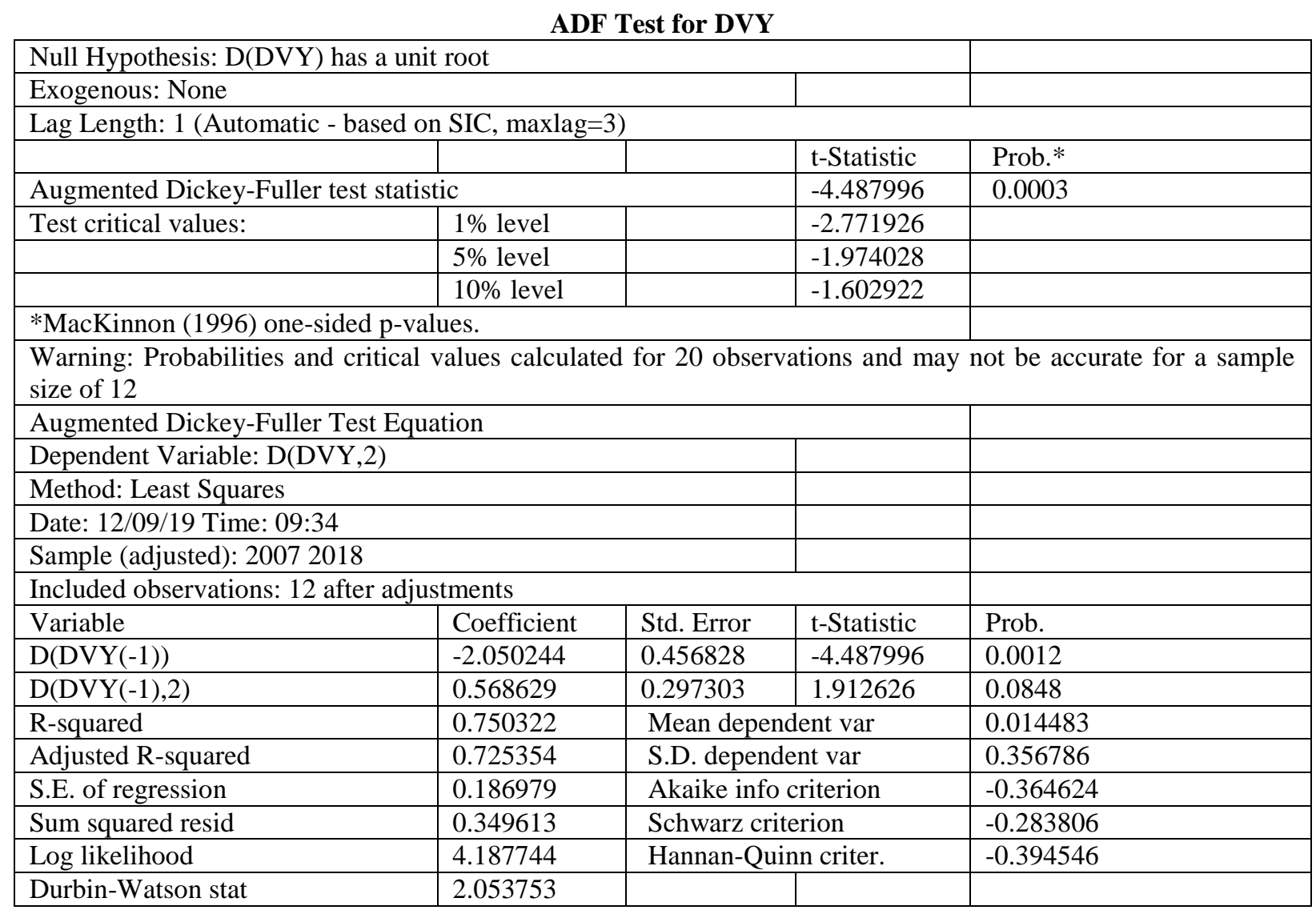




\section{Johansen Co-integration Test Results}

\begin{tabular}{|c|c|c|c|c|}
\hline \multicolumn{5}{|c|}{ Date: $12 / 09 / 19$ Time: 09:46 } \\
\hline \multicolumn{5}{|c|}{ Sample (adjusted): 20062018} \\
\hline \multicolumn{5}{|c|}{ Included observations: 13 after adjustments } \\
\hline \multicolumn{5}{|c|}{ Trend assumption: Linear deterministic trend (restricted) } \\
\hline \multicolumn{5}{|c|}{ Series: EQP DPR DVY } \\
\hline \multicolumn{5}{|c|}{ Lags interval (in first differences): 1 to 1} \\
\hline \multicolumn{5}{|c|}{ Unrestricted Cointegration Rank Test (Trace) } \\
\hline Hypothesized & & Trace & 0.05 & \\
\hline No. of CE(s) & Eigenvalue & Statistic & Critical Value & Prob.** \\
\hline None * & 0.902114 & 59.98333 & 42.91525 & 0.0005 \\
\hline At most $1 *$ & 0.806480 & 29.77202 & 25.87211 & 0.0155 \\
\hline At most 2 & 0.476793 & 8.421125 & 12.51798 & 0.2192 \\
\hline \multicolumn{5}{|c|}{ Trace test indicates 2 cointegrating eqn(s) at the 0.05 level } \\
\hline \multicolumn{5}{|c|}{$*$ denotes rejection of the hypothesis at the 0.05 level } \\
\hline \multicolumn{5}{|c|}{$* *$ MacKinnon-Haug-Michelis (1999) p-values } \\
\hline \multicolumn{5}{|c|}{ Unrestricted Cointegration Rank Test (Maximum Eigenvalue) } \\
\hline Hypothesized & & Max-Eigen & 0.05 & \\
\hline No. of CE(s) & Eigenvalue & Statistic & Critical Value & Prob.** \\
\hline None $*$ & 0.902114 & 30.21132 & 25.82321 & 0.0123 \\
\hline At most $1 *$ & 0.806480 & 21.35089 & 19.38704 & 0.0256 \\
\hline At most 2 & 0.476793 & 8.421125 & 12.51798 & 0.2192 \\
\hline \multicolumn{5}{|c|}{ Max-eigenvalue test indicates 2 cointegrating eqn(s) at the 0.05 level } \\
\hline \multicolumn{5}{|c|}{$*$ denotes rejection of the hypothesis at the 0.05 level } \\
\hline \multicolumn{5}{|c|}{ **MacKinnon-Haug-Michelis (1999) p-values } \\
\hline \multicolumn{5}{|c|}{ Unrestricted Cointegrating Coefficients (normalized by $\mathrm{b}^{\prime *} \mathrm{~S} 11^{*} \mathrm{~b}=\mathrm{I}$ ): } \\
\hline EQP & DPR & DVY & @ TREND(05) & \\
\hline-0.000174 & 24.07762 & 5.990744 & 0.164361 & \\
\hline$-8.24 \mathrm{E}-05$ & -14.70564 & -7.743628 & 0.290468 & \\
\hline$-5.11 \mathrm{E}-05$ & -10.95804 & -11.77313 & -0.131081 & \\
\hline \multicolumn{5}{|c|}{ Unrestricted Adjustment Coefficients (alpha): } \\
\hline $\mathrm{D}(\mathrm{EQP})$ & 10714.86 & 2283.655 & 3165.483 & \\
\hline $\mathrm{D}(\mathrm{DPR})$ & 0.009261 & 0.027780 & 0.002019 & \\
\hline $\mathrm{D}(\mathrm{DVY})$ & -0.133965 & -0.026276 & 0.045818 & \\
\hline \multicolumn{2}{|c|}{1 Cointegrating Equation(s): } & Log likelihood & -88.22765 & \\
\hline Normalized co & tegrating coe & ficients (standard & error in parenthes & es) \\
\hline EQP & DPR & DVY & @TREND $(05)$ & \\
\hline 1.000000 & -138580.0 & -34480.05 & -945.9860 & \\
\hline & $(20126.0)$ & $(11765.3)$ & $(230.506)$ & \\
\hline Adjustment co & ficients (stan & ard error in paren & heses) & \\
\hline D(EQP) & -1.861656 & & & \\
\hline & $(0.38821)$ & & & \\
\hline $\mathrm{D}$ (DPR) & $-1.61 \mathrm{E}-06$ & & & \\
\hline & $(1.9 \mathrm{E}-06)$ & & & \\
\hline $\mathrm{D}(\mathrm{DVY})$ & $2.33 \mathrm{E}-05$ & & & \\
\hline & $(5.2 \mathrm{E}-06)$ & & & \\
\hline 2 Cointegrating & Equation(s): & Log likelihood & -77.55220 & \\
\hline Normalized co & tegrating coe & ficients (standard & error in parenthes & \\
\hline EQP & DPR & DVY & @ TREND(05) & \\
\hline 1.000000 & 0.000000 & 21663.49 & -2072.900 & \\
\hline & & (14332.0) & $(340.658)$ & \\
\hline 0.000000 & 1.000000 & 0.405134 & -0.008132 & \\
\hline & & $(0.10042)$ & $(0.00239)$ & \\
\hline Adjustment co & ficients (stan & ard error in paren & heses) & \\
\hline $\mathrm{D}(\mathrm{EQP})$ & -2.049914 & 224405.8 & & \\
\hline & $(0.40066)$ & $(58780.0)$ & & \\
\hline $\mathrm{D}(\mathrm{DPR})$ & $-3.90 \mathrm{E}-06$ & -0.185546 & & \\
\hline & $(9.7 \mathrm{E}-07)$ & $(0.14213)$ & & \\
\hline $\mathrm{D}(\mathrm{DVY})$ & $2.54 \mathrm{E}-05$ & -2.839157 & & \\
\hline & $(5.5 \mathrm{E}-06)$ & $(0.80518)$ & & \\
\hline
\end{tabular}




\section{REFERENCES}

1. Baskin, J. (2005). Dividend policy and the volatility of common stock. Journal of portfolio management, 15(3), 19-25.

2. Adelegan, O. (2001). The impact of growth prospect, leverage and firm size on dividend behaviour of corporate firms in Nigeria. International journal of finance and management, 3(6), 432-511.

3. Adesola, O., \& Okowomg, E. W. (2009). Determinants of dividend policy of Nigeria listed firms. International journal of Finance and Economics, 12(8), 98-124.

4. Diamond, M. (2005). Earnings distribution and the evaluation of shares: Some recent evidence. Journal of financial and quantitative analysis, 2(01), 15-30.

5. Gordon, I. R., \& Molho, I. (1998). A Multi-stream Analysis of the Changing Pattern of Interregional Migration in Great Britain, 1960-1991. Regional Studies, 32(4), 309-323.

6. Miller, M. H., \& Modigliani, F. (1963). Dividend policy and market valuation: a reply. The Journal of Business, 36(1), 116-119.

7. Utami, S. R., \& Inanga, E. L. (2011). Agency costs of free cash flow, dividend policy, and leverage of firms in Indonesia. European Journal of Economics, Finance and Administrative Sciences, 33(6), 7-24.

8. Chen, J. (2009). Determinants of dividend policy: The evidence from New Zealand. International research journal of finance and economics. 34(15) 18-28.

9. Kalay, A. (1982). The ex-dividend day behavior of stock prices: a re-examination of the clientele effect. The Journal of Finance, 37(4), 1059-1070.

10. Hashemiyoo, A. (2012). The impact of initiating dividend payments on shareholders' wealth. Journal of business, 12(8), 77-96.

11. Kliger, D., \& Sarig, O. (2000). The information value of bond ratings. The journal of finance, 55(6), 2879-2902.

12. Botha, T., \& Von Blottnitz, H. (2006). A comparison of the environmental benefits of bagasse-derived electricity and fuel ethanol on a life-cycle basis. Energy policy, 34(17), 2654-2661.

13. Lease, R. A., \& Belfort, M. (2000). Riboregulation by DsrA RNA: trans-actions for global economy: MicroReview. Molecular microbiology, 38(4), 667-672.

14. Kaen, F. R., \& Baumann, H. D. (2003). Firm size, employees and profitability in US manufacturing industries. Employees and Profitability in US Manufacturing Industries (January 13, 2003).

15. Lintner, J. (1956). Distribution of incomes of corporations among dividends, retained earnings, and taxes. The American economic review, 46(2), 97-113.

16. Baker, H. K., Farrelly, G. E., \& Edelman, R. B. (1985). A survey of management view on dividend policy. International journal of finance management 14(13), 1007-1134.

17. Pruitt, S. W., \& Gitman, L. J. (1991). The interactions between the investment, financing, and dividend decisions of major US firms. Financial review, 26(3), 409-430.

18. Baker, H. K., \& Powell, G. E. (2000). Determinants of corporate dividend policy: A survey of NYSE firms. Journal of finance practice education 9(17), 29-40.

19. Amidu, M., \& Abor, J. (2006). Determinates of dividend payout ratios in Ghana. Journal of risk management and finance, 5(7), 136-145.

20. Brook, Y., Chalton, W., \& Hendershott, R. (1998). Do firms use dividends to signal large future cash flow increase. International Journal of finance management, 9(27), 46-57.

21. Alli, K., Khan, A., \& Ramirez G. (1993). Determinants of dividend policy: A factorial analysis. International Journal of finance, 17(28), 523-547.

22. Anil, K., \& Kapoor, S. (2008). Determinants of dividend payout ratios-a study of Indian information technology sector. International research journal of finance and economics, 15(1), 63-71.

23. Modigliani, F. (1982). Debt, dividend policy, taxes, inflation and market valuation. The Journal of Finance, 37(2), 255-273.

24. Truman, J. (1988). Letter to my husband: notes about mourning and recovery. Penguin Group USA.

25. Farrar, D. E., \& Selwyn, L. L. (1967). Taxes, corporate financial policy and return to investors. National tax Journal, 9(20), 44-462.

26. Partington, A. (2006). The linguistics of laughter: A corpus-assisted study of laughter-talk. Routledge.

27. Huggins, T. G., Wells-Knecht, M. C., Detorie, N. A., Baynes, J. W., \& Thorpe, S. R. (1993). Formation of o-tyrosine and dityrosine in proteins during radiolytic and metal-catalyzed oxidation. Journal of Biological Chemistry, 268(17), 12341-12347.

28. Higgins, B. H. (1990). Economic development: Problems, principles, and policies. Universal Book Stall.

29. Rozeff, M. S., \& O'Connor, P. F. (2000). GainLoss Portfolio Theory. Available at SSRN 241780.

30. Imran, M. I., \& Tharek, A. R. (2004, October). Radial line slot antenna development for outdoor point to point application at $5.8 \mathrm{GHz}$ band. In 2004 RF and Microwave Conference (IEEE Cat. No. 04EX924) (pp. 103-105). IEEE.

31. Dhillon, P. (1986). Corporate ownership, dividend policy, and capital structure under asymmetric information. Louisiana state University, agricultural \& Mechanical College 15(8), 563678. 
32. Rozeff, M. S. (1982). Growth, beta and agency costs as determinants of dividend payout ratios. Journal of financial Research, 5(3), 249259.

33. Lloyd, G. (1985). Das Patriarchat der Vernunft:" männlich" und" weiblich" in der westlichen Philosophie. Daedalus-Verlag.

34. Collins, M. C., Saxena, A. K., \& Wansley, J. W. (1996). The role of insiders and dividend policy: A comparison of regulated and unregulated firms. Journal of finance strategic, 7(9), 1-9.

35. D'souza, J., \& Megginson, W. L. (1999). The financial and operating performance of privatized firms during the 1990s. The Journal of Finance, 54(4), 1397-1438.

36. Gordon, M. J. (1962). The investment, financing, and valuation of the corporation. Homewood, IL: RD Irwin.

37. Fama, E., \& Bablak, H. (1963). Dividend policy of individual firms; An empirical analysis. Journal of the America statistics Association, 6(3) 11321161.

38. Rapuluchukwu, E. U. (2010). The efficient market hypothesis: Realities from the Nigerian stock market. Global Journal of Finance and Management, 2(2), 321-331.

39. Inegbedion, J. O. (2009). Assessing the difficulty index of course materials in National Open University of Nigeria. Journal of Educational Research, 12(1), 18-35.

40. Agwuegbo, S. O. N., Adewole, A. P., \& Maduegbuna, A. N. (2010). A random walk model for stock market prices.

41. Brummelhuis, R., \& Guegan, D. (2005). Multiperiod conditional distribution functions for heteroscedastic models with applications to VaR.

42. Gupta, R., \& Basu, K. P. (2007). International Business \& Economics research Journal."week form Efficiency: In Indian Stock Markets.

43. Ojimogho, E. S., Odjimogho, S. E., Eriyamremu, G. E., \& Aguebor-Ogie, B. (2010). Changes in ocular tissue lipid peroxidation and antioxidant enzymes of rabbits fed a wholly compounded
Nigerian diet containing excess cadmium levels. Biosci Res Commun, 22(6), 287-294.

44. Fama, E. F., \& French, K. R. (1995). Size and book-to-market factors in earnings and returns. The journal of finance, 50(1), 131-155.

45. Malkiel, B. G., \& Fama, E. F. (1970). Efficient capital markets: A review of theory and empirical work. The journal of Finance, 25(2), 383-417.

46. Gupta, N., \& Gedam, A. (2014). Testing of efficient market hypothesis: a study on Indian stock market. Journal of Business and Management, 16(8), 28-38.

47. Olowe, R. A. (2009). Stock return, volatility and the global financial crisis in an emerging market: The Nigerian case. International Review of Business Research Papers, 5(4), 426-447.

48. Mishra, A., Fischer, M. K., \& Bäuerle, P. (2009). Metal-free organic dyes for dye-sensitized solar cells: From structure: Property relationships to design rules. Angewandte Chemie International Edition, 48(14), 2474-2499.

49. Nazir, M. B. (2010). Electro hydraulic servo system: A practical guideline for control and optimization. VDM Publishing.

50. Hussainey, K., \& Al-Najjar, B. (2011). Futureoriented narrative reporting: determinants and use. Journal of Applied Accounting Research.

51. Rashid, A., \& Rahman, A. A. (2008). Dividend policy and stock price volatility: evidence from Bangladesh. The Journal of Applied Business and Economics, 8(4), 71.

52. Dagogo-Jack, S., Edeoga, C., Ebenibo, S., Nyenwe, E., Wan, J., \& Pathobiology of Prediabetes in a Biracial Cohort (POP-ABC) Research Group. (2014). Lack of racial disparity in incident prediabetes and glycemic progression among black and white offspring of parents with type 2 diabetes: the pathobiology of prediabetes in a biracial cohort (POP-ABC) study. The Journal of Clinical Endocrinology \& Metabolism,99(6), E1078-E1087. 